\title{
Efficiency of ventilators for intermediate care to deliver adequate FI02. a bench study
}

\author{
L Baboi ${ }^{*}$, S Guegan², C Guérin ${ }^{1,3}$ \\ From ESICM LIVES 2015 \\ Berlin, Germany. 3-7 October 2015
}

\section{Introduction}

There is an ongoing development of turbine powered ventilators able to support patients with mild acute respiratory failure in the intermediate care environment at the hospital. The capability for these home care ventilators to deliver adequate FI02 is an important endpoint for patient's safety.

\section{Objectives}

To compare on the bench the performance of ventilators for intermediate care to deliver appropriate FI02 when non vented (double limb) circuit was used.

\section{Methods}

Astral 150, Elisée 150, Trilogy 200 and Monnal T50 equipped with non-vented double limb circuit or equivalent were set in volume controlled mode (tidal volume $500 \mathrm{ml}$, breathing frequency 15 cycles $/ \mathrm{min}$, inspiratory time $0.8 \mathrm{sec}$, constant flow inflation shape, positive end expiratory pressure $5 \mathrm{cmH} 2 \mathrm{O}$ ) and connected to ASL 5000 lung model set in a condition mimicking COPD patient (compliance $75 \mathrm{ml} / \mathrm{cmH} 2 \mathrm{O}$, inspiratory and expiratory airways resistance 15 and $25 \mathrm{cmH} 2 \mathrm{O} / \mathrm{L} / \mathrm{s}$, respectively). Oxygen was supplemented by connecting the low pressure oxygen port at the rear of ventilator to the wall oxygen supply via a flow-meter. Three oxygen flow rates were delivered: 0,3 and $15 \mathrm{~L} / \mathrm{min}$. FI02 was measured with Citrex H4 ${ }^{\mathrm{TM}}$ (imtmedical, Switzerland) and continuously monitored at the screen of the device. Once FI02 reached a plateau oxygen administration was maintained for an additional one minute and FI02 was measured over the last 10 breaths of the recording at the steady state defined as changes in FI02 less than 10\% from the previous sampling window. The sampling rate was $200 \mathrm{~Hz}$. Citrex
H4 TM device was calibrated before each experiment. The values of FI02 were expressed as mean \pm SD. Comparisons were made by using two-factor ANOVA and multiple comparisons between ventilators by using Tukey test.

\section{Results}

The values of FI02 are shown in the table. There is a significant effect of both oxygen flow rate supplementation and ventilator $(\mathrm{P}<0.001$ for each) and a significant interaction between them $(\mathrm{P}<0.001)$. For any given level of oxygen flow rate supplementation all differences between multiple comparisons across ventilators were statistically significant.

\section{Conclusions}

Some ventilators were associated with significantly higher levels of FI02 than the others at any rate of oxygen supplementation. At $15 \mathrm{~L} / \mathrm{min}$ oxygen supplementation, FI02 was close to $100 \%$ with the Astral ventilator. These results might open some new opportunities, such as allowing walking even for intubated hypoxemic patients in sub-acute facilities, especially when devices offer good mobility and Sp02 monitoring.

\section{Table 1}

\begin{tabular}{llll}
\hline \multicolumn{5}{l}{ Oxygen supplementation } \\
\hline $0 \mathrm{~L} / \mathrm{min}$ & $3 \mathrm{~L} / \mathrm{min}$ & $15 \mathrm{~L} / \mathrm{min}$ \\
\hline Astral 150 & $22 \pm 0.0$ & $42 \pm 0.0$ & $99 \pm 0.0$ \\
\hline Elisée 150 & $21 \pm 0.0$ & $35 \pm 0.0$ & $94 \pm 0.0$ \\
\hline Monnal T 50 & $21 \pm 0.0$ & $40 \pm 0.0$ & $86 \pm 0.0$ \\
\hline Trilogy 200 & $22 \pm 0.0$ & $30 \pm 0.0$ & $62 \pm 0.0$ \\
\hline
\end{tabular}




\section{Authors' details}

${ }^{1}$ Hôpital de la Croix Rousse, Réanimation Médicale, Lyon, France. ${ }^{2}$ Ecole des

Haute Etudes Ingenieur, Lille, France. ${ }^{3}$ INSERM UMR 955, Créteil, France.

Published: 1 October 2015

doi:10.1186/2197-425X-3-S1-A269

Cite this article as: Baboi et al.: Efficiency of ventilators for intermediate care to deliver adequate FI02. a bench study. Intensive Care Medicine Experimental 2015 3(Suppl 1):A269.

\section{Submit your manuscript to a SpringerOpen ${ }^{\circ}$ journal and benefit from:}

- Convenient online submission

- Rigorous peer review

- Immediate publication on acceptance

- Open access: articles freely available online

- High visibility within the field

- Retaining the copyright to your article

Submit your next manuscript at $\gg$ springeropen.com 